\title{
ON THE MOSS FLORA OF MOULD BAY (PRINCE PATRICK ISLAND, CANADIAN ARCTIC ARCHIPELAGO)
}

\author{
O. M. AFONINA ${ }^{1}$, M. K. RAYNOLDS ${ }^{2} \&$ D. A. WALKER ${ }^{2}$ \\ К ФЛОРЕ МХОВ ЗАЛИВА МОУЛД (ОСТРОВ ПРИНС-ПАТРИК, \\ КАНАДСКИЙ АРКТИЧЕСКИЙ АРХИПЕЛАГ) \\ О. М. АФОНИНА ${ }^{1}$, М. К. РЕЙНОЛДС ${ }^{2}$, Д. А. УОЛКЕР ${ }^{2}$
}

Abstract

The annotated list of mosses on the results of the identification of the collection from Prince Patrick Island (Canadian Arctic Archipelago) gathered in summer 2004 is presented. The list includes 67 species, 10 from them - new for Island. Descriptions of investigated habitat types and occurring species in them are given.

Резюме

Приводится аннотированный список мхов по результатам обработки коллекции, собранной летом 2004 г. на острове Принс-Патрик (Канадский Арктический архипелаг). Список включает 67 видов, 10 из них являются новыми для острова. Дается характеристика изученных типов местообитаний и оценка встречаемости видов в их пределах.

\section{INTRODUCTION}

The moss flora of Mould Bay on Prince Patrick Island (Western Canadian Arctic) has been reasonably well studied compared to most other areas of the Canadian High Arctic; however, investigations conducted in summer 2004 as part of this study of patterned ground features across the arctic bioclimate gradient suggest that the region still offers new significant finds.

The first data on mosses of this area (93 species) were published by W. C. Steere (1955) as a result of identifications of collections made by the mammologist C. O. Handley, Jr. during the summer of 1949. In 1968 a bryological survey of this region was carried by M. Kuc and as a result 44 species were added to the list published by Steere (Kuc, 1971; 1973a). Later C. D. Bird reported 60 moss species for Mould Bay (Bird, 1975), from data collected during 1974.

In the summer of 2004, botanists from the University of Alaska, Dr. D. A. Walker, M. K. Raynolds, and some others, were carrying out a geobotanical investigation at Mould Bay on Prince Patrick Island as part of a study of the biocomplexity associated with small patterned-ground features (Walker
$\&$ al., 2003). They investigated plant communities on non-sorted circles, small non-sorted polygons, earth hummocks, and earth mounds. They collected the vascular plants, bryophytes, and lichens in 39 releves from four habitat types, all located within $2 \mathrm{~km}$ south of the runway at the station. The identification of this moss collection included 67 species, 10 of them new for Mould Bay. These data are the basis for the present paper.

LOCATION DESCRIPTION

Prince Patrick Island is situated in the Northwest Territories, in the western Canadian Arctic Archipelago. It is north of Banks Island and west of Melville Island, and is $15,848 \mathrm{~km}^{2}$ in size. Mould Bay is the site of a Canadian weather station on the southeastern coast of Prince Patrick Island, at $76^{\circ} \mathrm{N}-199^{\circ} \mathrm{W}$ (Fig. 1).

Prince Patrick Island is a low relief island composed of folded sedimentary rocks, many of which are carbonate bearing (Tedrow \& al., 1968). Mould Bay is in the Tundra Bioclimate Zone, in Subzone B (CAVM Team, 2003), or in the northern variant of the Arctic tundra subzone (Yurtsev, 1974 ; 1994). For the period 1971-2000, the mean annual temperature was $-17.5^{\circ} \mathrm{C}$, with mean July

1 - V. L. Komarov Botanical Institute Rus. Acad. Sci., Prof. Popov Str., 2, St. Petersburg, 197376 Russia

2 - Alaska Geobotany Center, Institute of Arctic Biology, University of Alaska P.O. Box 757000, Fairbanks, AK 99775-7000. USA 


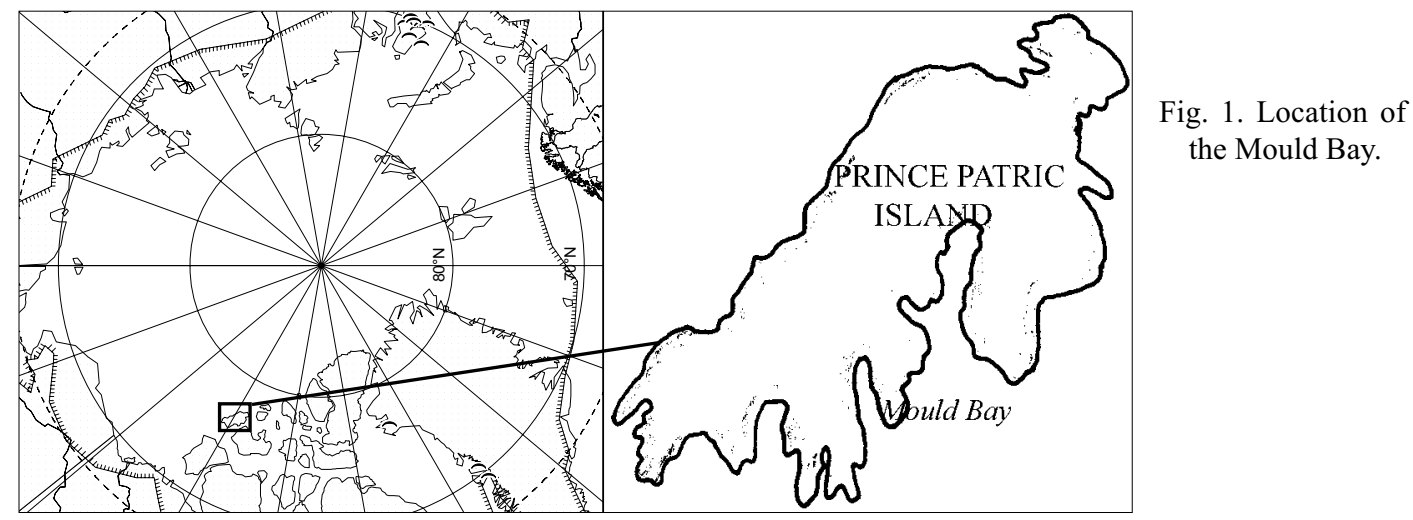

temperature of $+4.0^{\circ} \mathrm{C}$, annual precipitation -111 $\mathrm{mm}$, and average snow depth $-15 \mathrm{~cm}$.

Continuous vegetation at Mould Bay occurs in moist to wet areas with fine-grained soils, either on slopes below snowbeds or adjacent to lakes, streams, or the ocean. The vegetation is low-growing (3-5 cm height). The only woody shrubs recorded were the prostrate dwarf shrubs, Salix arctica and Dryas integrifolia. Large areas of sparsely vegetated gravel cover the hills and ridges around Mould Bay. While mostly barren, these areas do support scattered vascular plants, rock lichens, and occasional patches of vegetation in moist areas with finer soils. Patterned ground, due to sorting of soil and stones, occurs as sorted circles, stone nets, and stripes on slopes. Moist areas on slopes and broad ridges are covered with small non-sorted polygons that erode into small hummocks $(30-40 \mathrm{~cm}$ diameter and $5-15 \mathrm{~cm}$ high), which often have bare spots on the tops. The dominant vegetation on the hummocks is lichens and rushes (Luzula arctica). Mosses (dominated by Syntrichia ruralis and Sanionia uncinata), and prostrate dwarf shrubs (S. arctica and $D$. integrifolia) and forbs (Saxifraga oppositifolia, Parrya arctica, Potentilla hyparctica, Draba spp.) are common in between the hummocks. Wet areas below snowbeds or adjacent to ponds or streams are completely vegetated with moist to wet tundra plant communities, and are usually patterned with mounds (1-2 m diameter) or ice-wedge polygons (10-20 m diameter). Vegetation in these areas is dominated by sedges (Eriophorum triste), rushes (Luzula arctica), grasses (Alopecurus alpinus) and mosses (Tomentypnum nitens, Distichium spp., Ditrichum flexicaule, Orthothecium chryseon, Aulacomnium acuminatum), though lichens and Salix arctica are also common.
For the study of different patterned-ground plant communities in the Mould Bay area, two 10x10 m grids were established. Releves were sampled for the plant community types within each grid. Replicate releves were sampled in the area around the grids, giving 3-5 replicates for each community type. Releves were also sampled in two areas with mound patterning. A total of 39 releves were sampled. At each releve, location data and environmental site descriptions were recorded. Occurrence and cover abundance were recorded for all vascular and non-vascular plants, as well as summaries by lifeform. Reference collections were made of each species. A short description of the four habitat types follows. The vascular plant nomenclature is according to Porsild (1957), the moss nomenclature is given in general according to Ignatov \& Afonina (1992) and lichen nomenclature according to Esslinger (1997).

I. Small hummocks on ridge. $1 \mathrm{~km}$ southeast of Mould Bay runway and weather station (76 13'42.8" N; 119¹7'57.9" W). Small (15-20 $\mathrm{cm})$ hummocks on top of broad ridge. Hummocks covered with crustose (Lecanora epibryon), foliose (Hypogymnia subobscura), and fruticose (Thamnolia vermicularis var. subuliformis) lichens. In areas between hummocks: prostrate dwarf-shrub (Dryas integrifolia, Salix arctica), graminoid (Luzula arctica), forb (Saxifraga oppositifolia), moss (Syntrichia ruralis) tundra.

For this habitat type 32 moss species were recorded: Bryoerythrophyllum recurvirostrum, Bryum pseudotriquetrum, B. rutilans, Bryum sp., Drepanocladus arcticus, Cirriphyllum cirrosum, Ctenidium procerrimum, Didymodon asperifolius, D. icmadophillus, Distichium capillaceum, D. inclinatum, Ditrichum flexicaule, Encalypta al- 
pina, Hennediella heimii var. arctica, Hypnum revolutum, Mnium thomsonii, Myurella julacea, M. tenerrima, Orthothecium chryseon, O. strictum, Orthotrichum speciosum, Pohlia cruda, Polytrichastrum alpinum, Racomitrium lanuginosum, R. panshii, Sanionia uncinata, Schistidium papillosum, Syntrichia ruralis, Timmia austriaca, Tetraplodon mnioides, Tomentypnum nitens, Tortula leucostoma.

II. Dry, bare frost boils on sandy soil. $2 \mathrm{~km}$ southeast of Mould Bay runway and weather station (76²13' 33.2" N; $\left.119^{\circ} 17^{\prime} 32.0^{\prime \prime} \mathrm{W}\right)$. Sandy terrace at base of snowbed, patterned with flattopped, 1-2 m diameter polygons; mostly bare on top, with vegetation in cracks between polygons. Bare, sandy centers with very sparsely scattered forbs and fruticose lichens. Lichen-dominated edges. More fully vegetated areas between polygons: prostrate shrubs (Salix arctica, Dryas integrifolia), graminoids (Luzula arctica, Alopecurus alpinus, Festuca hyperborea), forbs (Parrya arctica, Oxyria digyna).

26 moss species were found in this habitat: Aulacomnium turgidum, Bryoerythrophyllum recurvirostrum, Bryum sp., Callialaria curvicaulis, Cirriphyllum cirrosum, Ctenidium procerrimum, Didymodon asperifolius, D. icmadophillus, D. rigidulus, Distichium inclinatum, Ditrichum flexicaule, Encalypta alpina, E. rhaptocarpa, Hypnum revolutum, $H$. vaucheri, Myurella julacea, Orthothecium chryseon, O. strictum, Pohlia cruda, Polytrichastrum alpinum, Racomitrium lanuginosum, R. panschii, Syntrichia ruralis, Timmia austriaca, Tortella arctica, Tortula mucronifolia.

III. Moist earth mounds below snow bed. 2 $\mathrm{km}$ south of Mould Bay runway and weather station ( $\left.76^{\circ} 13^{\prime} 36^{\prime \prime} \mathrm{N} ; 119^{\circ} 19^{\prime} 25^{\prime \prime} \mathrm{W}\right)$. Moist slope below snowbed, with 1-2 $\mathrm{m}$ in diameter vegetated mounds. Dominant plant species on the mounds were graminoids (Eriophorum triste, Arctagrostis latifolia), prostrate dwarf-shrubs (Salix arctica), mosses (Distichium inclinatum, Tomentypnum nitens, Ditrichum flexicaule) and lichens (Ochrolechia inaequatula, Lecanora epibryon). In moist troughs between mounds: mosses (Aulacomnium acuminatum, Bryum sp., Ditrichum flexicaule, Orthothecium chryseon), graminoids (Eriophorum triste), and prostrate dwarf shrub (Salix arctica).
This habitat had the richest moss assemblage of those examined with 45 species: Aplodon wormskjoldii, Aulacomnium acuminatum, A. turgidum, Bryoerythrophyllum recurvirostrum, Bryum cryophilum, B. pseudotriquetrum, B. rutilans, Bryum sp. (with capsules), Calliergon giganteum, Campylium stellatum, Catoscopium nigritum, Cinclidium arcticum, Cirriphyllum cirrosum, Cyrtomnium hymenophylloides, C. hymenophyllum, Dicranum acutifolium, D. spadiceum, Didymodon asperifolius, Distichium capillaceum, D. inclinatum, Ditrichum flexicaule, Drepanocladus arcticus, Encalypta alpina, Hylocomium splendens, Hypnum bambergeri, Limprichtia revolvens, Loeskypnum badium, Meesia triquetra, Mnium thomsonii, Myurella julacea, M. tenerrima, Oncophorus virens, O. wahlenbergii, Orthothecium chryseon, O. strictum, Philonotis fontana, P. tomentella, Platydictya jungermannioides, Pohlia beringiensis, Polytrichastrum alpinum, Pseudocalliergon brevifolium, Schistidium andreaeopsis, Tetraplodon mnioides, Timmia austriaca, Tomentypnum nitens, Tortella arctica.

IV. Wet earth mounds near coast. $1.5 \mathrm{~km}$ south of Mould Bay runway and weather station ( $\left.76^{\circ} 13^{\prime} 40^{\prime \prime} \mathrm{N} ; 119^{\circ} 20^{\prime} 02^{\prime \prime} \mathrm{W}\right)$. Wet earth mounds within $50 \mathrm{~m}$ of ocean shore. The mounds were about $1 \mathrm{~m}$ in diameter and about 20-25 cm high, with graminoid (Luzula arctica, Poa abbreviata), forb (Stellaria sp.), moss (Bartramia ithyphylla, Tortella arctica, Pseudocalliergon brevifolium), lichen (Lecidea sp., Lecidea ramulosa, Ochrolechia inaequatula) tundra vegetation.

25 moss species were identified from this site: Bartramia ithyphylla, Bryoerythrophyllum recurvirostrum, Bryum pseudotriquetrum, Bryum sp., Drepanocladus arcticus, Calliergon giganteum, Cinclidium arcticum, C. latifolium, Cirriphyllum cirrosum, Distichium capillaceum, D. inclinatum, Ditrichum flexicaule, Encalypta alpina, Fissidens cf. arcticus (single stem), Limprichtia revolvens, Myurella julacea, O. wahlenbergii, Orthothecium chryseon, Pohlia sp., Polytrichastrum alpinum, P. fragile, Pseudocalliergon brevifolium, Schistidium andreaeopsis, Tortella arctica, Warnstorfia sarmentosa.

\section{LIST OF MOSSES}

The distribution of species in habitat types is figured by Roman numerals. The frequency of 
each species was estimated on the basis of its occurrence on the releves as follows: very rare less than $1 \%$ cover on $1-2$ releves; rare - up to $5 \%$ cover on $3-4$ releves; sporadic - up to $5 \%$ cover on 5-9 releves; frequent but not abundant up to $5 \%$ cover on more than 9 releves; common - more than $5 \%$ cover on more than 9 releves. For some species growth form habit is noted (e.g. forms cushion, or grows as admixture), and the presence of sporophytes. The geographical grouping for each species is given, according to the classification accepted by Afonina and Matveyeva (2003) for the analysis of the moss flora of Bolshevik Island (Severnaya Zemlya Archipelago). All moss species recorded at the four habitat types at Mould Bay were classified into four geographical groups: arctic (A), arctomontane (AM), polyzonal $(\mathrm{P})$ and bipolar $(\mathrm{B})$. If a species was reported for Mould Bay earlier, the reference to the publications is given in parentheses, if a species is new for island it is marked by asterisk.

Aplodon wormskjoldii (Hornem.) Kindb. - III. Very rare on releves, but sporadic in investigated region, and widespread in the Canadian Arctic. On musk-ox scat. Forming pure, large cushion, with abundant developed sporophytes. A. (Steere, 1955; Kuc, 1971).

Aulacomnium acuminatum (Lindb. et Arnell) Kindb. -

III. Frequent. In the calcareous habitats typically forming pure and rather large cushions. AM. Species manly distributed in the Asian and American Arctic (Steere,1955; Kuc, 1971).

A. turgidum (Wahlenb.) Schwägr. - II, III. Frequent. Forming pure cushions and growing as admixture in polydominant cushions. AM. (Steere, 1955; Kuc, 1971; Bird, 1975).

Bartramia ithyphylla Brid. - IV. Abundant on wet mounds. Growing as admixture. B. in the Northern Hemisphere mainly as arctomontane (Steere, 1955; Kuc, 1971; Bird, 1975).

Bryoerythrophyllum recurvirostrum (Hedw.) P. C. Chen - I, II, III, IV. Frequent. Typically growing as admixture in polydominant cushions and having wide ecological amplitude. B. (Steere, 1955; Kuc, 1971).

Bryum cryophilum Martensson (B. obtusifolium Lindb.)

-IV. Rare. Forming pure cushion. AM. Species with predominant distribution in the Arctic (Steere, 1955; Kuc, 1971).

B. pseudotriquetrum (Hedw.) Gaertn., B. Mey. et Schreb. - II, III, IV. Frequent. Forming pure cushions and growing as admixture. B. (Kuc,1971).

B. rutilans Brid. (B. aeneum Blytt. ex B. S. G.) - I, III. Sporadic. Growing as admixture in polydominant cushions. AM. (Kuc, 1971). Noteworthy that many specimens of Bryum are sterile or scanty and cannot be identified to species.

Callialaria curvicaulis (Jur.) Ochyra (Cratoneuron curvicaule (Jur.) G. Roth) - III. Very rare. Growing as admixture. AM. (Kuc, 1971).

Calliergon giganteum (Schimp.) Kindb. - III, IV. Sporadic. Occurring as admixture. P. (Steere, 1955; Kuc, 1971; Bird, 1975). G. R. Brassard (1971) notes this species was common and abundant in the north-central part of Ellesmere Island but rare and absent from the extreme north coast.

Campylium stellatum (Hedw.) C. E. O. Jensen - III. Very rare. Growing as admixture. P. (Steere, 1955; Kuc, 1971; Bird, 1975).

Catoscopium nigritum (Hedw.) Brid. - III. Sporadic. P. (Steere, 1955; Kuc, 1971).

Cinclidium arcticum (B. S. G.) Schimp. - III, IV. Rare. Usually growing as admixture but sometimes forming pure cushions. AM. (Kuc, 1971). This species is common in tundra zone and rare in polar desert (Afonina \& Matveyeva, 2003).

Cinclidium latifolium Lindb. - IV. Rare. Growing as admixture. AM.. (Steere, 1955; Kuc, 1971).

Cirriphyllum cirrosum (Schwagr.) Grout - I, II, III, IV. Frequent. Growing as admixture and in pure cushions. AM. (Steere, 1955; Kuc, 1971; Bird, 1975). Widespread species in the Canadian Arctic (Kuc, 1973b).

Ctenidium procerrimum (Molendo) Lindb. (Pseudostereodon procerrimum (Molendo) M. Fleisch.; Hypnum procerrimum Molendo) - I, II. Frequent in dry habitats. Growing as admixture, also forming pure cushions. AM. A circumpolar species. Its role increases in High Arctic communities, and its ecological amplitude becomes broader (Steere, 1955; Kuc, 1971; Bird, 1975).

Cyrtomnium hymenophylloides (Hueb.) Nyholm ex T. J. Kop. (Mnium heterophylloides Hueb.) - III. Very rare. Growing as admixture. AM. (Steere, 1955; Kuc, 1971).

C. hymenophyllum (B.S.G.) Holmen (Mnium heterophyllum B. S. G.) - III. Rare. Growing as admixture but sometimes forming small pure cushions. AM. (Steere, 1955; Kuc, 1971).

*Dicranum acutifolium (Lindb. et Arnell) C. E. O. Jensen ex J. G. Weinm. - II, III. Rare. Occurring as admixture. AM. According to last floristical investigation this species has wide distribution in the Arctic.

D. spadiceum J. E. Zetterst. - III. Rare. Occurring as admixture. P. (Bird, 1975). The role of this species in High Arctic communities definitely decreases.

Didymodon asperifolius (Mitt.) H. A. Crum et al. (Didymodon rufus Lorentz) - I, II. Sporadic. Usually growing as admixture. AM. (Steere, 1955; Kuc, 1971; 
Bird, 1975). In the Arctic this species is represented by var. gorodkovii, which was described by A. Abramova and I. Abramov (Abramov, 1963) from Novisibirskie Islands. This taxon is characterized by almost smooth or poorly papillose cell walls. Many bryologists did not recognize it, though R. N. Schljakov (1999) considered this taxon as an independent species closely related to $D$. giganteus (Funk) Jur. A revision of Arctic material of this species is necessary to resolve this problem.

D. icmadophilus (Schimp. ex Mull. Hal.) K. Saito (Barbula icmadophila Schimp.) - I, II Frequent. Growing as admixture. AM. (Steere, 1955; Kuc, 1971).

D. rigidulus Hedw. - II. Very rare. Growing as admixture. P. Kuc (1971) reported for Mould Bay Didymodon sp. and noted that specimens similar to D. rigidulus. In our collection there are some specimens with Didymodon but this material are scanty and cannot be identified to species.

Distichium capillaceum (Hedw.) B. S. G. - I, III, IV. Frequent. Usually growing as admixture and sometimes forming pure small cushions. Sometimes occurs with sporophytes. B. (Steere, 1955; Kuc, 1971).

D. inclinatum (Hedw.) B. S. G. - I, II, III. Abundant. Usually growing as admixture in calcareous habitats. Sometimes occurring with sporophytes. AM. (Kuc, 1971).

Ditrichum flexicaule (Schwagr.) Hampe - I, II, III, IV. Abundant. Growing as admixture and forming pure cushions. B. (Steere, 1955; Kuc, 1971; Bird, 1975). The role of this species in High Arctic communities and its ecological amplitude increase, it is one of the most important moss species.

*Drepanocladus arcticus (R. S. Williams) Hedenäs (Campylium arcticum R. S. Williams) - I, III, IV. Sporadic. Forming cushions. A. Kuc (1971) has reported Campylium sp. for Mould Bay and noted that "under this name were placed specimens similar to C. $\operatorname{arcticum}(\mathrm{R}$. S. Williams) Broth. and C. zemliae C. E. O. Jensen. According to the revision of genus Campylium L. Hedenäs (1997), C. arcticum was transferred to the genus Drepanocladus.

Encalypta alpina Sm. - I, II, III, IV. Frequent. Usually growing as admixture. AM. (Kuc, 1971). Very common species in the Arctic.

E. rhaptocarpa Schwagr. - II. Rare. Growing as admixture. Rarely occurring with sporophytes. B. (Steere, 1955; Kuc, 1971; Bird, 1975).

*Fissidens cf. arcticus Bryhn - IV. Very rare (single stems). A. Rare arctic species with circumpolar distribution. It is known from Svalbard (Frisvoll \& Elvebakk, 1996), Greenland, Canada, Alaska (Steere \& Brassard, 1974), the Taimyr Peninsula (Kannukene \& Matveyeva, 1996) and the Yamal Peninsula (Czernyadjeva, 2000).
Hennediella heimii (Hedw.) R. H. Zander var. arctica (Lindb.) R. H. Zander (Desmatodon hemii var. arctica (Lindb.) Crum; Pottia heimii (Hedw.) Hampe var. arctica Lindb.) - I. Very rare. A. (Steere, 1955; Kuc, 1971; Bird, 1975).

Hylocomium splendens (Hedw.) B. S. G. - III. Sporadic. B. (Steere, 1955; Kuc, 1971; Bird, 1975).

Hypnum bambergeri Schimp. - III. Very rare. AM. (Steere, 1955; Bird, 1975). M. Kuc (1971) reported Hypnum bambergeri var. condensatum (Schimp.) Limpr. at Mould Bay, but H. Ando (1996) regards it is a form which is not sufficiently distinct to merit a varietal rank within $H$. bambergeri.

H. revolutum (Mitt.) Lindb. - I, II. Abundant in dry habitats. Growing as admixture and forming flat cushions. B. (Steere, 1955; Kuc, 1971; Bird, 1975).

H. vaucheri Lesq. - II. Rare. Growing as admixture. P. (Kuc, 1971; Bird, 1975).

Limprichtia revolvens (Sw.) Loeske (Drepanocladus revolvens (Sw.) Warnst.) - III, IV. Sporadic in moist and wet habitats. Growing as admixture and forming pure cushions. B. (Steere, 1955; Kuc, 1971; Bird, 1975).

Loeskypnum badium (C. Hartm.) H. K. Paul (Drepanocladus badius (C. Hartm.) G. Roth) - III. Very rare. Growing as admixture. AM. (Bird, 1975).

Meesia triquetra (Richter) Angstr. - III. Very rare. Growing as admixture. B. (Steere, 1955; Kuc, 1971).

Mnium thomsonii Schimp. (Mnium orthorhynchum Brid.) - I, III. Sporadic. Occurring as admixture, preferring dry habitats. AM. (Steere, 1955).

Myurella julacea (Schwagr.) B.S.G. - I, II, III, IV. Frequent. Growing as admixture. B. (Steere, 1955; Kuc, 1971; Bird, 1975).

Myurella tenerrima (Brid.) Lindb. - I, III. Sporadic. Growing as admixture. P. (Steere, 1955).

Oncophorus virens (Hedw.) Brid. - III. Very rare. Occurring as admixture. P. (Kuc, 1971).

O. wahlenbergii Brid. - III, IV. Frequent in moist and wet sites. Growing as admixture and forming pure cushions. P. (Steere, 1955; Kuc, 1971; Bird, 1975).

Orthothecium chryseon (Schwagr. ex Schult.) Schimp. (Holmgrenia chrysea (Schwagr.) Lindb.) - I, II, III, IV. Abundant. Growing as admixture and forming pure cushions. AM. (Steere, 1955; Kuc, 1971; Bird, 1975).

O. strictum Lorentz (Holmgrenia stricta Lor.) - I, II, III. Sporadic. Usually growing as admixture, preferring calcareous habitats. AM. (Steere, 1955).

Orthotrichum speciosum Nees (O. killiasii Mull. Hal.) - I. Frequent in dry habitats. Growing as admixture and forming pure cushions. P. (Steere, 1955; Kuc, 1971; Bird, 1975).

Philonotis fontana (Hedw.) Brid. - III. Rare. Growing as admixture and forming pure cushions. P. (Steere, 1955). 
P. tomentella Molendo (Philonotis fontana var. pumila (Turn.) Brid.) - III. Very rare. Growing as admixture. AM. (Kuc, 1971; Bird, 1975).

*Platydictya jungermannioides (Brid.) H. A. Crum III. Rare. Growing as admixture. B. Spread species in the Northern Hemisphere, rare and scattered in the Arcic.

*Pohlia beringiensis Shaw - III. Very rare. Growing as admixture in polydominant cushions. With propagules. A. Species with almost circumpolar distribution.

P. cruda (Hedw.) Lindb. - I, II. Sporadic. Growing as admixture. B. (Steere, 1955; Kuc, 1971; Bird, 1975).

Polytrichastrum alpinum (Hedw.) G. L. Sm. (Pogonatum alpinum (Hedw.) Rohl.) - I, II, III, IV. Frequent. This species has a wide ecological amplitude and occurs as an admixture in many communities. B. (Steere, 1955; Kuc, 1971; Bird, 1975).

*P. fragile (Bryhn) Schljakov - IV. Rare. Growing as admixture. A. This species is sometimes treated as variety $P$. alpinim and differs by having fragile leaves that are usually distinctly constricted at the line of dehiscence at the bases of limbs.

Pseudocalliergon brevifolium (Lindb.) Hedenäs (Drepanocladus brevifolius (Lindb.) Warnst.; D. latifolius (Lindb. et Arnell) Broth.) - III, IV. Frequent in wet mounds.. Forming pure cushions and growing as admixture. A. Reported for Mould Bay by by Steere (1955) and Kuc (1971) as Drepanocladus lycopodioides (Brid.) Warnst., but it is Pseudocalliergon brevifolium without doubt.

Racomitrium lanuginosum (Hedw.) Brid. - I, II. Sporadic. Growing as admixture and forming pure cushions. B. (Steere, 1955; Kuc, 1971; Bird, 1975).

*R. panschii (Mull. Hal.) Kindb. - I, II. Rare. Occurring as admixture. A. This species may have been reported earlier for Mould Bay by Steere (1955), Kuc (1971) and Bird (1975) as R. canescens Brid. s.l.

Sanionia uncinata (Hedw.) Loeske (Drepanocladus uncinatus (Hedw.) Warnst.) - I. Abundant in drier localities. Occurring as admixture. B. (Steere, 1955; Kuc, 1971; Bird, 1975).

*Schistidium andreaeopsis (Mull. Hal.) Laz. - III, IV. Very rare. Growing as admixture. Arctic species with Asiatic-American distribution. Bird (1975) reported Grimmia apocarpum var. nigrescens Mol. at Mould Bay - it is quite possible that it was $S$. andreaeopsis.

*S. papillosum Culm. - I. Very rare. Growing as admixture. AM. According to H. Blom (1996) it is the most widespread of species in the Schistidium apocarpum complex.

${ }^{*} S$. orientale L. I. Savicz - Near sewage lagoon. Very rare. Forming large cushion, composed of many hemi-isophyllous plants. Superficially these plants show some similarity to $S$. pylaesii or $S$. cyclophyl- lum as have nearly unbranched shoots and short branches with smaller leaves than the stem leaves. This material was identified byK. I. Flatberg. P. Species with Asiatic - North American distribution. In North America Sphagnum orientale is known from arctic and central Alaska; Beverly Lake, Northwest Territories; Pangnirtung, Baffin Island; northern Manitoba; and Yukon Territory (Crum, 1986). In Asia, this species is reported from Western Siberia; it is rather widely distributed in East Siberia, and the Far East (from Chukotka to Primorski Krai) (Ignatov \& Afonina, 1992; Afonina \& Czernyadjeva, 1995). Prince Patrick Island is the farthest north locality within Sphagnum orientale's distribution.

Syntrichia ruralis (Hedw.) F. Weber et D. Mohr (Tortula ruralis (Hedw.) P. Gaertn., Meyer et Schreb.) - I, II. Abundant in dry localities. Usually grows as admixture in polydominant moss communities, but sometimes forms few cushions. B. (Steere, 1955; Kuc, 1971; Bird, 1975).

Tetraplodon mnioides (Hedw.) B.S.G. - I, III. Rare. Forming pure cushions. With sporophytes. B. (Steere, 1955; Kuc, 1971; Bird, 1975 as Tetraplodon mnioides var. cavifolius Schimp.).

Timmia austriaca Hedw. - I, II, III. Frequent. Usually growing as admixture. AV. (Steere, 1955; Kuc, 1971; Bird, 1975).

Tomentypnum nitens (Hedw.) Loeske - I, II, III. Abundant. Occurring in many habitats but avoids very wet and salt. P. (Steere, 1955; Bird, 1975).

Tortella arctica (Arnell) Crundwell et Nyholm - II, III, IV. Abundant on wet mounds. Usually forming pure cushions. A. (Bird, 1975). Species with distribution mainly in Asia and North America.

Tortula leucostoma (R. Br.) Hook. et Grev. (Desmatodon leucostomus (R. Br.) Berggr.) - I. Rare. Growing as admixture. With sporophytes. AM. (Steere, 1955; Kuc, 1971).

T. mucronifolia Schwagr. - II. Very rare. Growing as admixture. P. (Steere, 1955; Kuc, 1971; Bird, 1975).

Warnstorfia sarmentosa (Wahlenb.) Hedenäs (Calliergon sarmentosum (Wahlenb.) Kindb., Sarmentypnum sarmentosum (Wahlenb.) Tuom. et T. J. Kop.) - IV. Rare. Growing in wet habitats. B. (Steere, 1955, Kuc, 1971).

The most common and frequently occurring species in the investigated habitat types are Bryoerythrophyllum recurvirostrum, Cirriphyllum cirrosum, Distichium capillaceum, Ditrichum flexicaule, Encalypta alpina, Myurella julacea, Orthothecium chryseon, Polytrichastrum alpinum These species were recorded in all four types of habitats. Other common and frequently occurring species were recorded in three types of habitats: 
Bryum pseudotriquetrum, Distichium inclinatum, Timmia austriaca, Tomentypnum nitens, Tortella arctica. These species are in general bipolar and arctomontane except Tomentypnum nitens which is polyzonal species with circumpolar distribution.

The frequently occurring or abundant species of dry habitat types (I and II) are Ctenidium procerrimum, Didymodon icmadophilus, Hypnum revolutum, Orthotrichum speciosum, Sanionia uncinata, Syntrichia ruralis. The group of common species of moist and wet habitats (III and IV) with such occurring consists of Aulacomnium acuminatum, Bartramia ithyphylla Oncophorus wahlenbergii, Pseudocalliergon brevifolium,.

Twelve species have sporadic frequency, among them the species preferring calcareous or eutrophic conditions - Catoscopium nigritum, Drepanocladus arcticus, Didymodon asperifolius and Orthothecium strictum that form usually rather large cushions in suitable habitats. Such species as Calliergon giganteum, Hylocomium splendens, Limprichtia revolvens were recorded in wet habitats, and Racomitrium lanuginosum in dry one. Others species with sporadic frequency grow as admixture in polydominant cushions - Bryum rutilans, Mnium thomsonii, Myurella tenerrima, Pohlia cruda.

Rare species form the largest group including 29 species. Among them are rare species worldwide-Cyrtomnium hymenophyllioides, Fissidens arcticus, Pohlia beringiensis, Schistidium andreaeopsis; and species with scattered distribution and sporadic frequency - Callialaria curvicaulis, Didymodon rigidulus, Tortula leucostoma, Tortula mucronifolia. This group also includes species that form rather common smaller parts of plant communities in the tundra zone, but which are rare or absent in the High Arctic: Campylium stellatum, Cinclidium arcticum, C. latifolium, Cyrtomnium hymenophylloides, Dicranum acutifolium, D. spadiceum, Loeskypnum badium, Meesia triquetra, Oncophorus virens, Philonotis fontana, P. tomentella, Sphagnum orientale. Rare occurrence of some species (Bryum cryophilum, Encalypta rhaptocarpa, Hypnum bambergeri, $H$. vaucheri, Politrichastrum fragile, Racomitrium panschii, Schistidium papillosum, Warnstorfia sarmentosa) in investigated habitats in Mould Bay is not quite clear, it is very likely that it is caused by lack of suitable condition for their growth.

There are some species occurring in specific habitats - Aplodon wormskjoldii, Tetraplodon mnioides which grow on decomposing carcasses of animals or all kinds of animal droppings; and Hennediella heimii var. arctica which grows on bare calcareous soil rich in salts (usually near the sea).

Taking into account all available data from the literature, 148 species are know for the moss flora of Mould Bay at present. It is interesting that this moss flora is very similar to Somnitelnaja Bay on Wrangel Island, which is in the same Tundra Bioclimate Zone as Mould Bay (Subzone B or Arctic Tundra from the point of view of Yurtsev (1994)).

\section{ACKNOWLEDGEMENTS}

The authors are grateful to Kjell I. Flatberg from Botanical Department of University of Trondheim, Norway, for the identification of Sphagnum orientale, and to Patrick Kuss for the collection. The work was partly supported by Russian Foundation for Basic Researches (projects 03-04-49400). Field work was supported by the US National Science Foundation (Grant No. OPP-0120736).

\section{LITERATURE CITED}

[ABRAMOV, I. I.] АБРАМОВ, И. И. 1963. Мхи Новосибирских островов. - [Bryophytes of Novosibirske islands] Tр. Аркт. Антаркт. ин-та. [Trudy Arct. Antarct. Inst.] 224: 206-221.

AFONINA, O. M. \& I. V. CZERNYADJEVA 1995. Mosses of the Russian Arctic: check-list and bibliography. - Arctoa 5: 99-142.

[AFONINA, O. M. \& N. V.MATVEYEVA] АФОНИНА, О. М., Н. В. МАТВЕЕВА 2003. Мхи острова Большевик (архипелаг Северная Земля). - [Mosses of the Bolshevik island (Severnaya Zemlya archpelago] Бот. журн. [Bot. Zhurn.] 88(9): 1-24.
ANDO, H. 1996. Studies on the genus Hypnum Hedw. (X).Hikobia 12: 9-17.

BIRD, C. D. 1975. The lichen, bryophyte, and vascular plant flora and vegetation of the Landing lake area, Prince Patrick Island, Arctic Canada. - Can. J. Bot. 53(8): 719-744.

BLOM, H. H. 1966. A revision of the Schistidium apocarpum complex in Norway and Sweden. - Bryophytorum Bibl. 49: 1-333.

BRASSARD, G. R. 1971. The mosses of Northern Ellsmere Island, Arctic Canada. II. Annotated list of the taxa. - Bryologist 74(3): 282-311. 
CAVM Team. 2003. Circumpolar Arctic Vegetation Map (Scale 1:7,500,000). Conservation of Arctic Flora and Fauna (CAFF) Map No. 1, U.S. Fish and Wildlife Service, Anchorage, AK.

CRUM, H. 1986. Sphagnaceae - Illustrated moss flora of arctic North America and Greenland. 2. - Medd. Groenland, Biosci. 18: $1-61$

CZERNYADJEVA, I. V. 2000. Fissidens arcticus Bryhn in Russia. - Arctoa 9: 25-28.

CZERNYADJEVA, I. V. 2001. Moss flora of Yamal Peninsula. - Arctoa 10: 121-150.

ESSLINGER, T. L. 1997. A cumulative checklist for the lichen-forming, lichenicolous and allied fungi of the continental United States and Canada. North Dakota State University: http://www.ndsu.nodak.edu/instruct/esslige/checklist/checklist7.htm 9 (First Posted 1 December 1997, Most Recent Update 17 July 2002) Fargo, North Dakota, USA.

FRISVOLL, A. A. 1981. Fifteen bryophytes new to Svalbard, including notes on some rare or interesting species. - Lindbergia 7: 91-102.

FRISVOLL, A.A. \& A. ELVEBAKK 1996. Part 2. Bryophytes. - In: Elvebakk A., Prestrund P. (eds.): A catalogue of Svalbard plants, fungi, algae and cyanobacteria. Norsk polarinstitutt Skifer 198: 57-172.

HEDENÄS, L. 1997. A partial generic revision of Campylium (Musci). - Bryologist 100(1): 65-88.

IGNATOV, M. S. \& O. M. AFONINA (eds.) 1992. Check-list of mosses of the former USSR. - Arctoa 1(1-2): 1-85.

KANNUKENE, L. \& N. MATVEYEVA 1996. Mosses from the Arctic tundra of the Taimyr Peninsula, Siberia. - Proc. Estonia Acad. Biol. 45(1/2): 51-67.

KUC, M. 1971. Bryoflora of the Mould Bay area, Prince Patrick Island, its geobotanical differentiation and age. Nova Hedwigia 22(3-4): 659-674.

KUC, M. 1973a. Addition to the arctic moss flora. VI. - Moss- flora of Masik River valley (Banks island) and its relationship with plant formations and the Postglacial history. Rev. Bryol. et Lichünol. 39(2): 253-264.

KUC, M. 1973b. Bryogeography of Expedition Area, Axel Heiberg Island, N. W. T., Canada.-Bryophytorum. Bibl. 2: $1-120$

PORSILD, A.E. 1957. Illustrated flora of the Canadian Arctic Archipelago. - Bull. Natl. Mus. Canada 146: 1-209.

[SCHLJAKOV, R. N.] ШЛЯкОВ, P. H. 1999. Новые названия некоторых таксонов мхов России. - [New names of some taxa of Russian mosses] Новости сист. низи. pacm. [Novosti Sist. Nizsh. Rast.] 33: 196-198.

STEERE, W. C. 1955. Bryophyta of arctic America. VI. A collection from Prince Patric Island. - Amer. Midland Naturalist 53(1): 231-241.

STEERE, W. C. \& G. R. BRASSARD 1974. The systematic position and geographical distribution of Fissidens arcticus. - Bryologist 77(2): 195-202.

TEDROW, J. C. F., P. F. BRUGGEMANN, G. F. WALTON 1968. Soils of Prince Patrick Island. Office of Naval Research Technical Report (ONR-352-4). - Arctic Institute of North America, Washington D.C. Research Paper No. 4482 .

WALKER, D. A., H. E. EPSTEIN, W. A. GOULD, A. M. KELLEY, A. N. KADE, J. A. KNUDSON, W. B. KRANTZ, G. MICHALESON, R. A. PETERSON, C. L. PING, M. A. RAYNOLDS, V. E. ROMANOVSKY \& Y. SHUR. 2004. Frost-boil ecosystems: complex interactions between landforms, soils, vegetation, and climate. - Permafrost and Periglacial Processes 15: 171-188.

[YURTSEV, В. А.] ЮРЦЕВ, Б. А. 1974. Проблемы ботанической географии Северо-Восточной Азии. [Problems of phytogeography of Northeastern Asia] Л., Наука [Leningrad, Nauka], 160 pp.

YURTSEV, B. A. 1994. Floristic division of the Arctic. $-J$. Veg. Sci. 5: 765-776. 